\title{
Dry fermented buffalo sausage with sage oil extract: Safety and quality
}

\author{
By Ferial M. Abu Salem and Hayam M. Ibrahim*
}

\author{
Food Technology Dept., National Research Center, Dokki, Cairo, Egypt \\ ( ${ }^{*}$ Corresponding author: hm_ibrahim2002@yahoo.com)
}

\section{RESUMEN}

\section{Embutidos de búfalo con extractos de salvia: cali- dad y seguridad}

Extractos de aceite de salvia fueron añadidos a embutidos de carne de búfalo. Las características químicas, microbiológicas y sensoriales de los embutidos fueron evaluadas durante el periodo de maduración. En particular, $\mathrm{pH}$, oxidación lipídica, aminas biogénicas y microflora fueron analizadas. Los resultados de este estudio indican que los extractos de aceite de salvia, como antioxidantes naturales, podrían ser utilizados en embutidos preparados con carnes de búfalo, con objeto de obtener un producto final con unos niveles de aminas biogénicas y de oxidación lipídica aceptable, así como con una calidad sensorial mejorada.

PALABRAS CLAVE: Aminas biogénicas - Calidad sensorial - Embutidos - Extracto de aceite de salvia - Oxidación lipídica - Periodo de maduración.

\section{SUMMARY}

Dry fermented buffalo sausage with sage oil extract: Safety and quality

Sage oil extract was added during the preparation of dry fermented buffalo meat sausage. Some chemical, microbial and sensory characteristics of sausages were evaluated during the ripening period. In particular, $\mathrm{pH}$, lipid oxidation, biogenic amines and micro flora were analyzed. Results of this study pointed out that sage oil extract as natural antioxidant could be utilized in dry fermented sausage, prepared from buffalo meat, in order to obtain a final product within acceptable lipid oxidation and biogenic amine levels, as well as improved sensory quality.

KEY-WORDS: Biogenic amines - Dry fermented sausage Lipid oxidation - Overall sensory quality - Ripening period Sage oil extract.

\section{INTRODUCTION}

Dry fermented sausage is a popular, common food item and produced commercially in various parts of the world. The quality of the final dry fermented sausage product is closely related to the ripening that takes place during drying. This process, which confers to a product its particular slicing ability, firmness, color and flavor, is characterized by a complex interaction of chemical and physical reactions associated with the microbiological development of the batter flora
(Ordonez et al., 1999). Lactobacillus, Micrococcus and Staphylococcus genera play an important role during fermentation and ripening of fermented sausage. Lactic acid bacteria enhance the physico-chemical properties of sausages and restrict the growth of some undesirable microorganisms (Gonzales and Diez 2002; Samelis et al., 1998). Ferreira et al., (2006) indicated that fermented sausages are considered safe foods due to the reduction in water activity and $\mathrm{pH}$ that occurs during processing and storage and inhibits the development of pathogenic bacteria.

Lipid oxidation is one of the major problems occurring during processing and storage of meat and meat products. This oxidation decreases the quality and safety of food stuff and initiates several changes which adversely affect the product's color, flavor, texture and nutritional values; also yielding many compounds that contribute to the pathogenesis of cancer, atherosclerosis, heart and allergic diseases (Mielnik et al., 2008 and Tang et al., 2001).

In order to inhibit the development of oxidative reactions in meat products, natural and synthetic antioxidants have been commonly used in the meat industry (Estevez and Cava, 2006). Spices and herbs, generally, used in food stuffs for enhancing the flavor or color attributes, have antimicrobial as well as antioxidant activity (Baydar et al., 2004; Sağdic and Ǒzcan 2003;Yanishlieva and Marinova, 2001). It has been reported that dried herbs and essential oils have been successfully used to reduce lipid oxidation in meat products (Estevez and Cava, 2006). Natural antioxidants have been reported to be more powerful than the synthetic antioxidants especially rosemary, sage and green tea extracts (Tang et al., 2001; Wanasundara and Shahidi, 1998; Yanishlieva and Marinova, 2001; Zandi and Gondon, 1999). Sage (Salvia Officinalis) is a popular Labiatae herb with a verified potent antioxidant activity. The effectiveness of sage essential oil as antioxidant has been demonstrated in a large variety of food stuffs including refrigerated beef (Djenane et al., 2003), frozen pork patties (McCarthy et al., 2001). The antioxidant activity of sage essential oil is mainly related to two phenolic di-terpenes: carnosic acid and carnosol which are considered two effective free radical scavengers (Dorman et al., 2003; Ibanez et al., 2003).

Biogenic amines are basic nitrogenous compounds found in a wide variety of foods such as sausages (Hernandez-Jover et al., 1997a) and meat (Vinci and 
Antonelli, 2002). The presence of biogenic amines in food constitutes a potential public health concern due to their physiological and toxicological effects. Biogenic amines can be produced during storage or processing of the products by thermal or bacterial enzymatic decarboxylation of free amino acids, growing on meat and in meat fermentation or exposed to microbial contamination during processing or storage, may contain biogenic amines (Önal, 2007). The production of biogenic amine depends on the quality of raw materials and hygienic conditions in the processing environment. Latorre-Moratalla et al., (2008) found that amine contents and profiles may vary depending on several extrinsic and intrinsic factors during the manufacturing process such as ripening conditions, formulation, physico-chemical and proteolytic parameters, as well as micro flora development and its decarboxylase activity. It is important to monitor biogenic amine levels in fresh and processed foods not only due to their toxicity but they can also be a useful index of spoilage or ripening and a good indication of freshness as reported by Önal, (2007). Some biogenic amines (mainly cadaverine and histamine) have been proposed as chemical indicators of the hygienic conditions of raw material and/or manufacturing practices since accumulation is associated with the activity of contaminant bacteria (Bover-Cid et al., 2003; Halasz et al., 1994 and Hernandez-Jover et al., 1997b). Dry fermented sausages are worldwide diffuse fermented meat products that can be a source of biogenic amines. In fact, the high amount of proteins in these meat products and the proteolyic activity during ripening provide the precursors for decarboxylase activity of starter cultures and wild micro flora (Suzzi and Gardini, 2003).The safety of dry fermented sausage for consumer could depend partially on the content of biogenic amines (BA), such as histamine, tyramine, putrescine and cadaverine; which might represent a food poisoning hazard. (De La Rivas et al., 2008).

From a safety and quality view point, the aim of the present study was to evaluate chemical $(\mathrm{pH}$, biogenic amines (BA), 2-Thiobarbituric acid reaction substances (TBARS), microbiological (aerobic plate counts (APC), lactic acid bacteria count (LAB) and the sensory (Overall sensory quality) characteristics of dry fermented sausage, prepared from buffalo meat with added sage oil extract, as natural antioxidant, during the ripening period.

\section{MATERIALS AND METHODS}

\subsection{Materials}

Fresh buffalo meat and fat were obtained from a local slaughter house. Spices, salt, sugar, olive oil and sage herb (Salvia officinalis) in dry form were purchased from a local supermarket. A starter culture mixture of Pediococcus acidilactici, Lactobacillus plantarum and Staphylococcus carnosus was purchased from Biocarna (Wiesby, Germany).

\subsection{Extraction of sage (Salvia officinalis) oil}

The separation of essential oil from the dried sage herb was carried out by steam distillation for $3 \mathrm{~h}$. The steam distillation apparatus used includes a glass boiler heated by an electric resistance, a glass extraction chamber and a modified Clevenger trap with graduated tube. The essential oil was dried over anhydrous calcium sulfate and stored in a dark glass bottle (Bozkurt, 2006; Cassel et al, 2009).

\subsection{Dry fermented sausage preparation}

The sausage batter was prepared from: $900 \mathrm{~g}$ lean buffalo meat mixed with $200 \mathrm{~g}$ fat, $18.0 \mathrm{~g}$ salt, $4.5 \mathrm{~g}$ sugar, $21 \mathrm{~g}$ dry garlic, $5.5 \mathrm{~g}$ cumin, $1.0 \mathrm{~g}$ cinnamon, $0.5 \mathrm{~g}$ clove, $5.5 \mathrm{~g}$ red pepper, $11.0 \mathrm{~g}$ black pepper, $2.0 \mathrm{~g}$ olive oil and $0.2 \mathrm{~g}$ starter culture mixture. The meat was minced in a meat grinder. All other ingredients except the fat were added and mixed with the minced meat in a cutter for $\sim 15 \mathrm{~min}$ at $5 \pm 1{ }^{\circ} \mathrm{C}$. During the mixing, the starter culture mixture was added. The prepared sausage batter was divided into three parts then sage oil extract was added as follows: the first part was the control (sample A1) without adding the sage oil extract, the second and third parts (samples A2 and A3) were prepared by adding 0.025 and $0.05 \%$ sage oil extract respectively. Each batch was incubated at $4{ }^{\circ} \mathrm{C}$ for $12 \mathrm{~h}$. The refrigerated fat was then added to each sausage batter and mixed well into a cutter. Each sausage batter was stuffed into artificial collagen casings (Naturin RL2, Germany), of $38 \mathrm{~mm}$ in diameter under clean conditions using a filling machine. Duplicate batches were prepared for each batter. Each sausage batch had duplicate samples, and each sausage was $\sim 100 \mathrm{~g}$ in weight. The sausages were ripened (fermented and maturated) for 15 days as follows: 2 days at $90 \pm 2 \% \mathrm{RH}$ and 26 $\pm 1^{\circ} \mathrm{C}$, 2days at $85 \pm 2 \% \mathrm{RH}$ and $24 \pm 1{ }^{\circ} \mathrm{C}$, 2days at $80 \pm 2 \% R H$ and $22 \pm 1{ }^{\circ} \mathrm{C}$, 2days at $75 \pm 2 \% R H$ and $20 \pm 1{ }^{\circ} \mathrm{C}, 2$ days at $70 \pm 2 \% \mathrm{RH}$ and $18 \pm 1{ }^{\circ} \mathrm{C}$, 3days at $65 \pm 2 \% \mathrm{RH}$ and $18 \pm 1{ }^{\circ} \mathrm{C}$, and 2days at 60 $\pm 2 \% \mathrm{RH}$ and $18 \pm 1^{\circ} \mathrm{C}$. Sausage samples from each batch of batter were taken directly after the stuffing of batter into casings on days $0,2,4,6,8,10,13$ and 15 of ripening for the determination of $\mathrm{pH}$, TBARS, and BA (histamine, tyramine and putrescine) formation. Also, on days $0,4,8,13,15$ of ripening the changes in APC, LAB and sensory attributes were recorded. Prior to analyses, sausages were homogenized in a food processor to provide homogenous and representative samples. The analyses were carried out in duplicate. Sensory attributes were evaluated in the whole sausage sample and on the cut surface.

\subsection{Analytical determinations}

$p H$

A sausage sample $(10 \mathrm{~g})$ was homogenized in 100 $\mathrm{ml}$ distilled water and the $\mathrm{pH}$ values were determined 
using a digital pH-meter (HANNA, HI 902 meter, Germany).

\section{Thiobarbituric acid reactive substances (TBARS)}

The TBARS values were determined spectrophotometricaly according to Byun et al., (2001). Homogenized sausage samples (2g) were taken and TBARS were extracted twice with $10 \mathrm{ml}$ of $0.4 \mathrm{M}$ perchloric acid. Extracts were collected and made up to $25 \mathrm{ml}$ with $0.4 \mathrm{M}$ perchloric acid and then centrifuged for $5 \mathrm{~min}$ at $1790 \mathrm{~g}$. After centrifugation, $1 \mathrm{ml}$ of the extract was poured into a glass test-tube with a stopper. TBARS reagent $(5 \mathrm{ml})$ was added and the extract was heated in a boiling water bath for $35 \mathrm{~min}$. After cooling in tap-water, the absorbance of the sample was read against the appropriate blank at $538 \mathrm{~nm}$. A standard curve was prepared using 1,1,3,3-tetraethoxypropane (TEP).

\section{Biogenic amines}

Histamine, tyramine and putrescine were extracted as follows: five grams of the sample were blended with $25 \mathrm{ml} \mathrm{5 \%}$ trichloroacetic acid. Filtration was achieved using filter paper whatman No.1. Five ml. of the extract were transferred into a suitable culture tube with $4 \mathrm{~g}$ $\mathrm{Na} \mathrm{Cl}$ and $1 \mathrm{ml}$ of $50 \% \mathrm{Na} \mathrm{OH}$ then shaken for 2 min. Centrifugation was carried out for $5 \mathrm{~min}$ at $5000 \mathrm{xg}$ and the upper layer was transferred to a $50 \mathrm{ml}$ separating funnel. To the upper layer extract, $15 \mathrm{ml}$ of $\mathrm{n}$-heptane were added and extracted 3 times with $1 \mathrm{ml}$ portions of $0.2 \mathrm{~N} \mathrm{HCl}$. The extracts were collected in a glass tube with stopper and evaporated to dryness using a water bath at $95^{\circ} \mathrm{C}$ with the aid of a gentle current of air. This was followed by the formation of dansylamines as described by Maijala and Eerola, (1993a). Biogenic amine concentrations were determined according to Deabes, (2000) using the HPLC. The HPLC system was equipped with a (Waters 600) delivery system. HPLC column: Reverse phase C18 Nucleosil column 250x4 mm, $10 \mu \mathrm{m}$ packing, (Macherey-Naggl). The detection was performed using a U.V detector (waters 486 ) at $254 \mathrm{~nm}$ wavelength, using a linear program of $25 \mathrm{~min}$. period and $1 \mathrm{ml} / \mathrm{min}$ constant solvent flow rate. Data were integrated and recorded using a Millennium Chromatography. Manger software 2010, (Waters, Milford MA 01757).

\section{Aerobic plate count (APC)}

Aerobic plate counts were carried out using the spread plate method on aerobic plate count agar (Merck, Darmstadt, Germany). Petri dishes were incubated for 24-72 h at $37^{\circ} \mathrm{C}$ (Erkmen, 2000).

\section{Lactic acid bacteria count ( $L A B)$}

LAB counts were measured using the spread plate method on De Man, Rogosa and Sharp agar (MRS; Merck, Darmstadt, Germany). Petri dishes were incubated for $48-72$ h. at $30{ }^{\circ} \mathrm{C}$ (Erkmen, 2000).

\section{Sensory evaluation}

Sensory attributes (flavor, color of cut surface, and ease of cutting) of $25 \mathrm{~g}$ dry fermented sausage samples were determined at intervals during the ripening period, twice for each sample, by a panel of 10 trained panelists. Panelists gave scores for each sample, with respect to their perceptions of flavor and color as: 1 (worst) to 10 (best). Cutting scores were evaluated as 1 that is not sliced, to 10 which is sliced perfectly. The overall sensory quality scores of sausages was determined from the same expression described by Bozkurt and Erkmen (2004) as:

$$
\begin{aligned}
& \text { Overall sensory quality }=(\text { flavor } \times 0.50)+ \\
& \quad+(\text { color } \times 0.25)+(\text { cutting } \times 0.25)
\end{aligned}
$$

\section{Statistical analysis}

The obtained data were subjected to analysis of variance (ANOVA) according to Snedecor and Cochran (1990) using the MstatC program. Duncan's Multiple Range Tests were used to compare between means of treatments according to Waller and Duncan (1969) at probability $\alpha 0.05$ level.

\section{RESULTS AND DISCUSSION}

\section{1. $\mathrm{pH}$ values}

A sharp decrease $(p<0.05)$ was noticed in the $\mathrm{pH}$ values on the $2^{\text {nd }}$ day of the ripening period from 6.9 to $4.52,4.54$ and 4.57 in sausage samples A1, A2 and $A 3$, respectively (Fig.1). This sharp decrease is important due to the inhibition of undesired bacteria, the rate of conversion of color and the formation of desired flavor in dry fermented sausage (Luke, 1994). Maijala et al.,(1993b) and Bover-Cid et al.,(2001) reported that a sharp rapid decrease in $\mathrm{pH}$ caused by amine-negative starter cultures can largely prevent biogenic amine accumulation in sausage and reduce the growth of amine-positive microorganisms. A correlation between biogenic amine production and the decrease in $\mathrm{pH}$ in sausage caused by lactic fermentation has been proven . (Eitenmiller et al., 1978; Santos-Buelga et al., 1986).

During the $4^{\text {th }}$ to $15^{\text {th }}$ days of the ripening period the $\mathrm{pH}$ values increased from 4.69 to reach 5.53 in the control sausage sample (A1), 5.58 and 5.61 in sausage samples (A2 and $A 3$ ) mixed with $0.025 \%$ and $0.05 \%$ sage oil extract respectively. This increase could be due to the destruction of formed organic acid. These findings agree with the previously results of Kayaardi and Gok, (2003) and Vural, (1998) who indicated that the production of organic acids by bacteria might be the cause for the noticed decrease in $\mathrm{pH}$, also, the observed increase in $\mathrm{pH}$ values might be due to the decomposition of acids and the formation of basic 


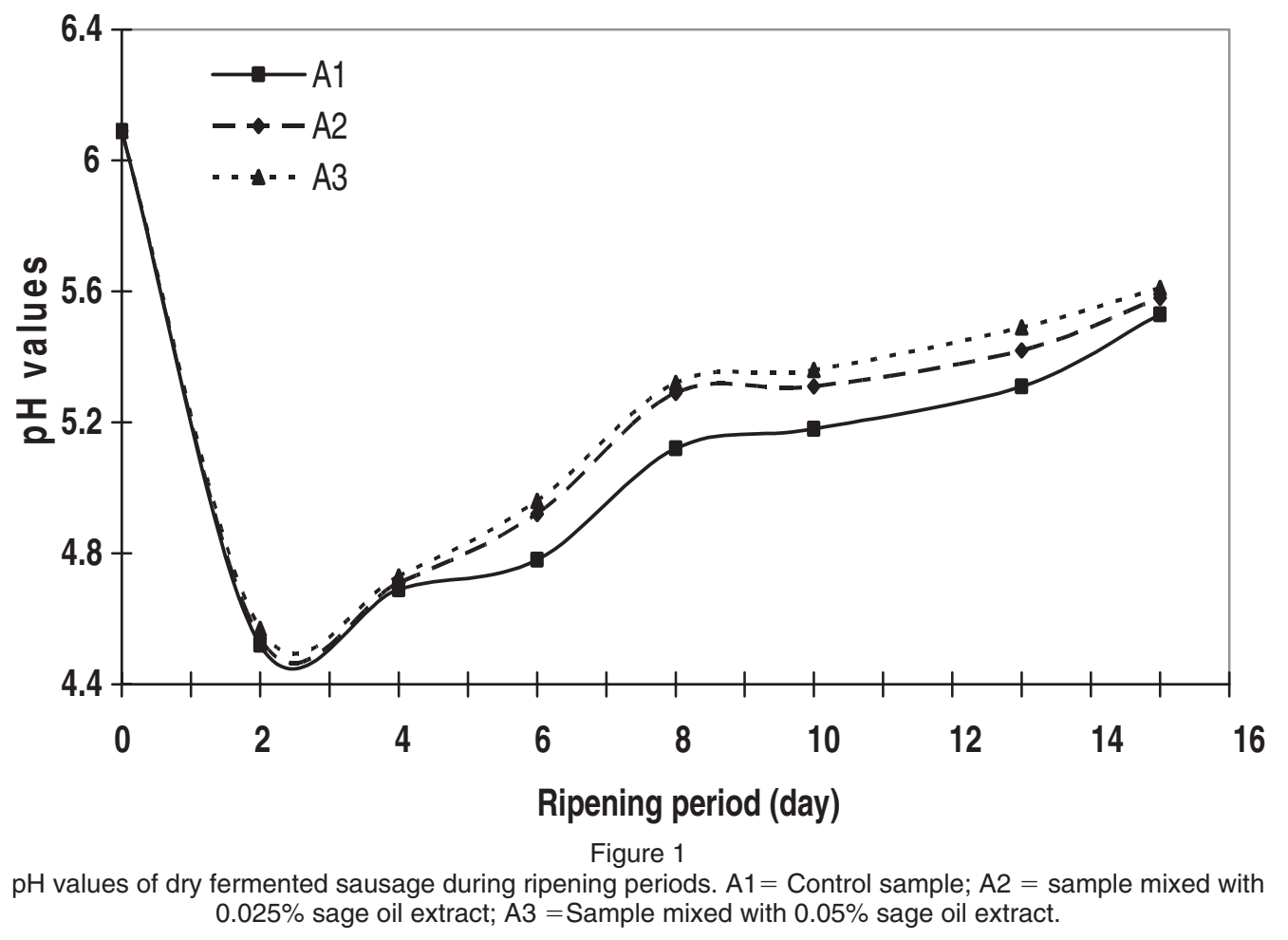

nitrogenous compounds. Generally, it was noticed that $\mathrm{pH}$ values were not affected significantly by the addition of sage extract $(0.025$ or $0.05 \%)$.

\subsection{Thiobarbituric acid reactive substances (TBARS)}

The Data presented in (Table 1) show the changes of TBARS values in the prepared dry fermented sausage samples during the ripening period. Ripening time and addition of sage extract as natural antioxidant were found to affect significantly $(p<0.05)$ the TBARS values of the sausage samples. TBARS values increased gradually during the first 8 days of the ripening period in $A 1, A 2$, and $A 3$ samples. The highest TBARS values were noticed at the $8^{\text {th }}$ day of the ripening period in sausage sample $A 1$. The rate of TBRAS formation (lipid oxidation) was noticed to be higher through days 4-6 than during other periods and then decreased and became nearly constant during the other ripening periods. At the end of the ripening period TBARS values were $0.96,0.51$ and $0.46 \mathrm{mg} /$ $\mathrm{kg}$ in A1 (control), A2 and A3 samples respectively. The decrease after the $8^{\text {th }}$ day could be due to the formed thiobarbituric acid substances being lost by further reaction. Statistical analysis indicated that the

Table 1

TBARS (mg malonaldehyde / $\mathrm{kg}$ meat) of the dry fermented sausage during the ripening period*

\begin{tabular}{|c|c|c|c|c|c|c|c|c|}
\hline \multirow{3}{*}{$\begin{array}{l}\text { Ripening } \\
\text { Period }^{*} \\
\text { (day) }\end{array}$} & \multicolumn{6}{|c|}{ Samples } & \multirow{2}{*}{\multicolumn{2}{|c|}{$\begin{array}{c}\text { Main effect } \\
\text { of period }\end{array}$}} \\
\hline & \multicolumn{2}{|c|}{ A1 } & \multicolumn{2}{|c|}{ A2 } & \multicolumn{2}{|c|}{ A3 } & & \\
\hline & Mean & SD & Mean & SD & Mean & SD & Mean & SD \\
\hline 0 & $0.19 \mid$ & \pm 0.028 & $0.19 \mid$ & \pm 0.028 & $0.19 \mid$ & \pm 0.028 & $0.19 \mathrm{~g}$ & \pm 0.022 \\
\hline 2 & $0.28 \mathrm{jk}$ & \pm 0.028 & $0.26 \mathrm{k}$ & \pm 0.028 & $0.24 \mathrm{kl}$ & \pm 0.014 & $0.26 f$ & \pm 0.026 \\
\hline 4 & $0.38 \mathrm{i}$ & \pm 0.028 & $0.35 i$ & \pm 0.028 & $0.33 \mathrm{ij}$ & \pm 0.028 & $0.35 \mathrm{e}$ & \pm 0.031 \\
\hline 6 & $0.92 c$ & \pm 0.014 & $0.74 \mathrm{ef}$ & \pm 0.014 & $0.70 f$ & \pm 0.042 & $0.79 \mathrm{~b}$ & \pm 0.107 \\
\hline 8 & $1.18 a$ & \pm 0.028 & $0.81 d$ & \pm 0.028 & $0.76 \mathrm{de}$ & \pm 0.042 & $0.92 a$ & \pm 0.207 \\
\hline 10 & $0.98 b$ & \pm 0.028 & $0.56 \mathrm{~g}$ & \pm 0.014 & $0.51 \mathrm{gh}$ & \pm 0.028 & $0.68 c$ & \pm 0.232 \\
\hline 13 & $0.97 b c$ & \pm 0.028 & $0.54 \mathrm{~g}$ & \pm 0.014 & $0.48 \mathrm{~h}$ & \pm 0.014 & $0.66 d$ & \pm 0.240 \\
\hline 15 & $0.96 b c$ & \pm 0.014 & $0.51 \mathrm{gh}$ & \pm 0.028 & $0.46 \mathrm{~h}$ & \pm 0.028 & $0.64 d$ & \pm 0.247 \\
\hline $\begin{array}{l}\text { Main effect } \\
\text { of sample }\end{array}$ & $0.73 a$ & \pm 0.371 & $0.50 \mathrm{~b}$ & \pm 0.212 & $0.46 c$ & \pm 0.197 & & \\
\hline
\end{tabular}

Means with different letters within each column are significant at $\alpha 0.05$.

${ }^{*}$ Ripening at $(\mathrm{RH}) 90-60 \%$, at $25-18^{\circ} \mathrm{C}$. SD $=$ Standard Deviation.

$\mathrm{A}_{1}=$ control sample.

$A_{2}=$ sample mixed with $0.025 \%$ sage oil extract.

$A_{3}=$ sample mixed with $0.05 \%$ sage oil extract. 
sage extract used decreased $(p<0.05)$ the TBARS values of sausage samples. The highest TBARS values were noticed in the control sample (A1); while the lowest were in the A3 sample mixed with $0.05 \%$ sage oil extract. This can indicate that sage oil extract as a natural antioxidant was effective against TBARS formation. Chen et al., (1999); Estevez et al., (2004); Formanek et al., (2001); McCarthy et al., (2001) reported that dried herbs and their essential oils have been successfully used to reduce lipid oxidation in meat products.

\subsection{Biogenic amines}

Biogenic amines (histamine, tyramine and putrescine) were not detected in the investigated sausage samples at zero time of the ripening period. During the first 6 days of the ripening period, histamine concentrations increased significantly $(p<0.05)$ up to 240.36, 175.63 and $160.32 \mathrm{mg} /$ $\mathrm{kg}$ in sausage samples $\mathrm{A} 1, \mathrm{~A} 2$ and $\mathrm{A} 3$ respectively (Fig.2) a similar increase in histamine levels was observed by Dierick et al., (1974) during the first days of sausage ripening. At the $10^{\text {th }}$ day of the prepared sausage ripening period a decrease in histamine levels $(p<0.05)$ was noticed to reach $185.21,138.05$ and $129.63 \mathrm{mg} / \mathrm{kg}$ in $\mathrm{A} 1, \mathrm{~A} 2$ and A3 samples respectively and then at the end of the ripening period (15 days) its concentrations increased $(p<0.05)$ to $270.52 \mathrm{mg} / \mathrm{kg}$ in the control sample (A1) and in $A 2$ and $A 3$ sausage samples reached 178.01 and $158.92 \mathrm{mg} / \mathrm{kg}$ respectively. Ruiz-capillas and Jiminez Colmenero, (2004) reported that histamine concentration varied from $0-200 \mathrm{mg} / \mathrm{kg}$ in dry cured sausage. While, Senoz et al., (2000) found the concentration of histamine in Turkish dry-sausage in the range of 6.7-362.2 $\mathrm{mg} / \mathrm{kg}$. Worth noting is the fact that the highest histamine level found was in the control sausage sample(A1) without sage extract while the lowest level was in the sample (A3) mixed with $0.05 \%$ sage oil extract. It can be concluded that histamine concentration was affected $(p<0.05)$ by ripening time and the addition of sage oil extract either 0.025 or $0.05 \%$; however, the addition of $0.05 \%$ sage oil extract was more effective than $0.025 \%$ in the reduction of histamine levels.

The production of biogenic amines is an extremely complex phenomenon, depending on several variables, such as the growth of microorganisms, their proteolytic and decarboxylase activities, which interact with each other. Tyramine and putrescine are the most common biogenic amines found in dry fermented sausages and their presence is often due to the activity of LAB (Suzzi and Gardini, 2003).

Tyramine has been systematically reported as the most abundant amine in fermented sausages (Coïsson et al., 2004 and Komprda et al., 2004). Sausage ripening time had a significant effect $(p<0.05)$ on tyramine formation, its concentration in the tested dry fermented sausage samples $(A 1, A 2$ and $A 3)$ increased significantly $(p<0.05)$ during the ripening period and reached 238.51, 142.63 and $136.21 \mathrm{mg} / \mathrm{kg}$ in samples $\mathrm{A} 1, \mathrm{~A} 2$ and A3 respectively at the end of the ripening period (Fig 3). Eerola et al., (1997) observed that tyramine concentration in sausages increased during 7 days of storage at $4{ }^{\circ} \mathrm{C}$. The permitted level of tyramine in foods is $100-800 \mathrm{mg} / \mathrm{kg}$, while $1080 \mathrm{mg} / \mathrm{kg}$ is toxic (Shalaby, 1996). Tyramine concentrations, in the present study, were found to be in the safe range and within the permitted level. Using sage extract as a natural antioxidant was found to significantly reduce $(p<0.05)$ tyramine formation. The reduction of tyramine in the A3 sausage sample with $0.05 \%$ sage oil extract (natural antioxidant) was about $43 \%$. Duncan's multiple range test indicated that the highest tyramine concentration was observed in the control sample (A1), and the lowest was for the dry fermented sausage sample with $0.05 \%$ sage extract

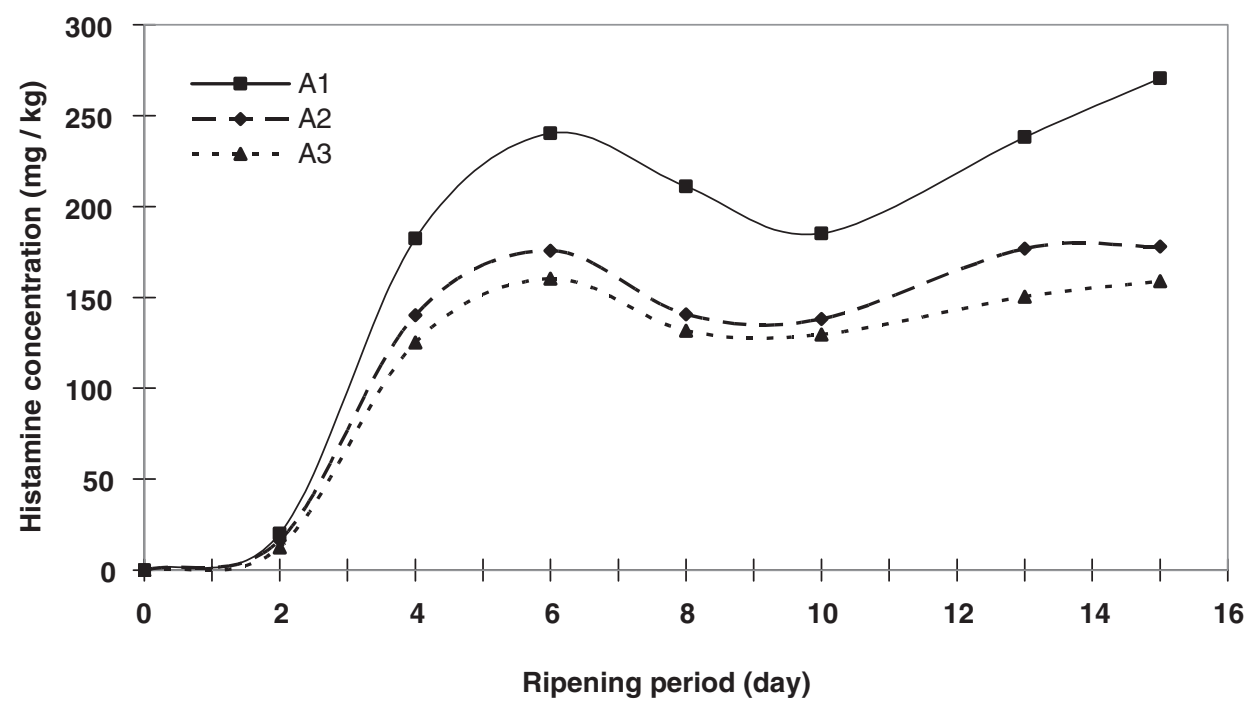

Figure 2

Histamine concentration in dry fermented sausage during ripening periods. $\mathrm{A} 1=$ Control sample; A2 = Sample mixed with $0.02 \%$ sage oil extract; $A 3=$ Sample mixed with $0.05 \%$ sage oil extract. 


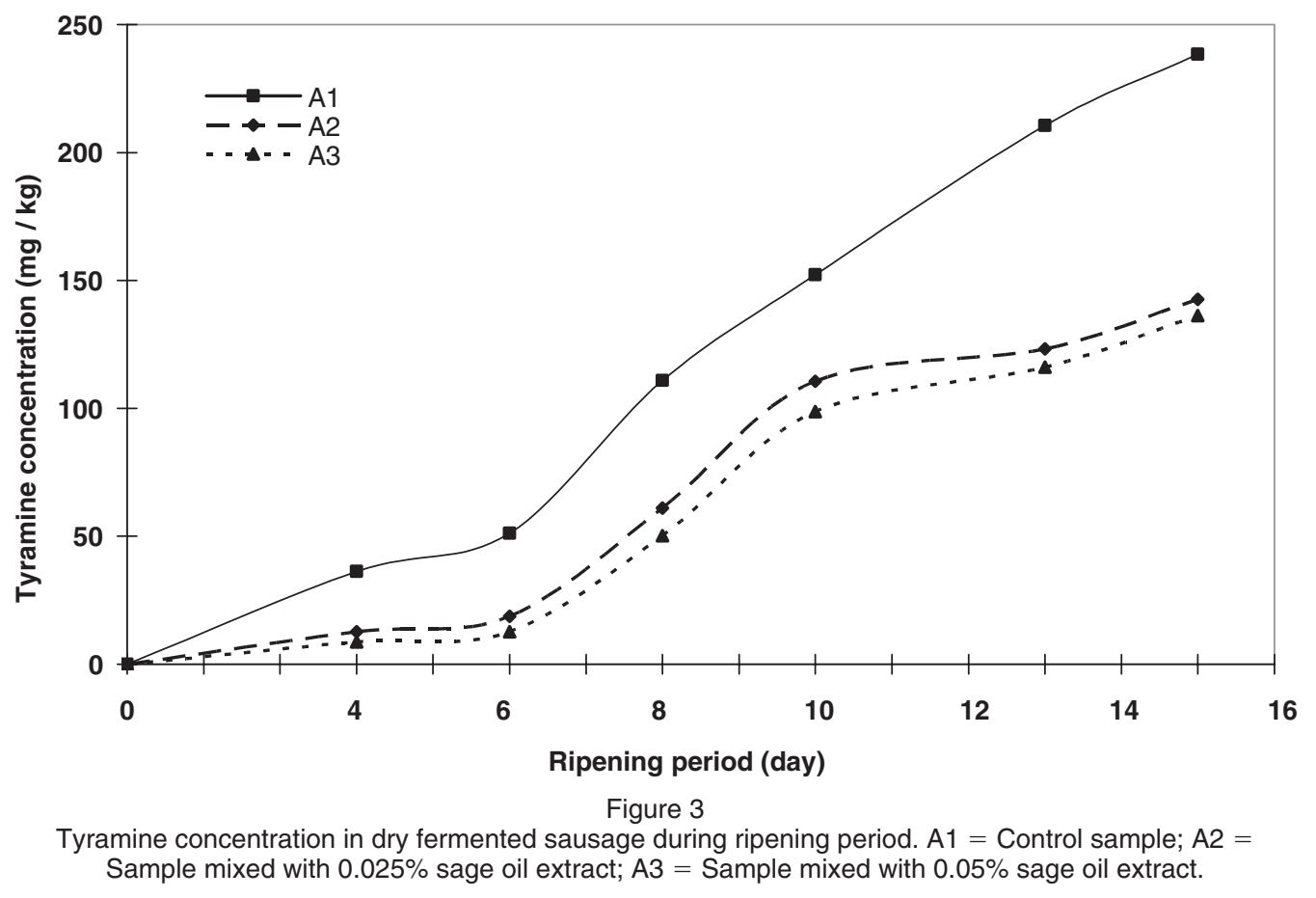

(A3). The decrease in tyramine formation by natural antioxidants e.g sage extract is important with respect to human health because tyramine causes migraine headaches, increased blood pressure and an increase in noradrenalin as reported by RuizCapillas and Jiminez-Colmenero, (2004).

Putrescine formation depends on the total aerobic viable count where a high total aerobic count results in high putresine formation (RuizCapillas and Jiminez- Colmenero, 2004). In the present study the addition of 0.025 and $0.05 \%$ sage extract as natural antioxidant to the prepared dry fermented sausage and the ripening time affected significantly the formation of putrescine. Its concentration increased up to 165.78, 120.93 and $110.56 \mathrm{mg} / \mathrm{kg}$ during the first 6 days of ripening in A1, A2 and A3 samples respectively (Fig.4). At the $8^{\text {th }}$ day, putrescine concentration decreased $(p<$ 0.05 ) to $129.93,82.53$ and $71.62 \mathrm{mg} / \mathrm{kg}$ in the tested sausage samples (A1, A2 and $A 3)$ respectively. It was observed at the end of ripening period that the addition of sage extract decreased significantly putrescine formation in the tested sausage samples. The highest putrescine concentration was observed in the control sample (A1), while the lowest was for sample A3 (with $0.05 \%$ sage oil extract). Duncan's multiple range test indicated that sage extract decreased $(p<0.05)$ the putrescine formation in the following order: sample A3 with $0.05 \%$ sage extract $>$ sample $A 2$ with $0.025 \%$ sage extract $>A 1$, the control sample. Thus, the addition of $(0.025$ or $0.05 \%)$ sage extract was effective for reducing the formation of putrescine. This reduction could be also due to the antimicrobial activities of sage extract. Antimicrobial activities of green tea extract and the Lamiaceae family (sage is one member of the Lamiaceae family) have been reported previously (Baydar et al., 2004; Higdon and Frei, 2003; Manzocco et al., 1998; Tang et al., 2001).

\subsection{Aerobic plate count (APC)}

The microorganisms that are primarily involved in sausage fermentation include species of Lactic acid bacteria (LAB), Gram-positive, catalasepositive cocci (GCC), moulds, and yeasts (Leroy et al., 2006). In the present study, it was noticed that APC in control sample (A1) without sage oil extract increased from 5.21 to 6.12 (Log CFU/g) during the first 8 days of ripening (Fig 5 ) and then decreased to $3.93(\mathrm{Log} \mathrm{CFU} / \mathrm{g})$ at end of the ripening period. This increase during the first 8 days of ripening could be due to high relative humidity $(90-75 \% \mathrm{RH})$ and temperature $\left(26-20{ }^{\circ} \mathrm{C}\right)$ and then decreased at $60 \% \mathrm{RH}$ and $18{ }^{\circ} \mathrm{C}$. Also, APC were 6.08 and 6.00 (Log CFU/g) for sausage samples mixed with sage oil extract ( $\mathrm{A} 2$ and $\mathrm{A} 3$ ) respectively at the $8^{\text {th }}$ day; then decreased to 3.75 and 3.61 (Log $\mathrm{CFU} / \mathrm{g}$ ) at the end of the ripening period. APC in sausage samples $A 2$ and $A 3$ were lower than the corresponding count for the control sample (A1). This can indicate that APC changed significantly with ripening time and addition of sage extract. Samelis et al., (1998); Bozkurt and Erkmen, (2004) found that APC increased during the ripening period and decreased during storage.

\subsection{Lactic acid bacteria (LAB)}

Concerning the microbiological status of the prepared fermented sausages, a statistical analysis (Fig.6) was performed and indicated that ripening time and addition of sage oil extract affected LAB counts during the ripening (fermentation and 


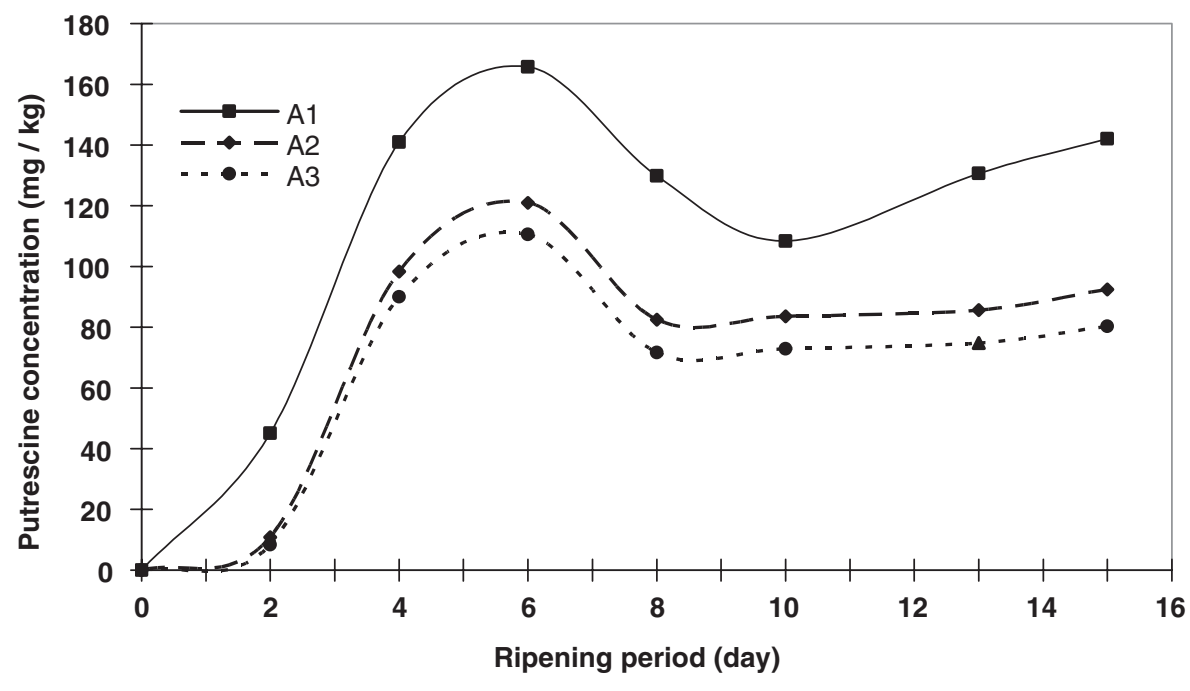

Figure 4

Putrescine concentration in dry fermented sausage during ripening period. $\mathrm{A} 1=$ Control sample; A2 = Sample mixed with $0.025 \%$ sage oil extract; A3 = Sample with $0.05 \%$ sage oil extract.

drying) period. A gradual increase in LAB count was observed during the first 8 days of ripening from 4.60 up to $5.22,5.21$ and 5.20 (Log CFU/g) in $\mathrm{A} 1, \mathrm{~A} 2$ and $\mathrm{A} 3$ samples, respectively followed by a slight decrease in LAB count at the $13^{\text {th }}$ and $15^{\text {th }}$ days of sausage ripening. The $L A B$ count decrease ranged from 4.99 (log CUF/g) in sample A3 (mixed with $0.05 \%$ sage oil extract) to 5.01 (log CUF/g) in sample $A 1$ (control) at the end of the ripening period (15 days). It seemed that the increase or decrease in $L A B$ counts was nearly constant during the ripening period. This agrees with Samelis et al., (1998); Roig-Saguse et al., (1999); Bruna et al., (2001) and Gonzales and diez (2002) who found that $L A B$ increased during the ripening period and decreased during the storage period. Worth mentioning is the fact that food fermenting lactic acid bacteria ( $L A B)$ are generally considered to be not toxinogenic or pathogenic (Suzzi and Gardini 2003).

\subsection{Overall sensory quality evaluation}

Lipid oxidation and other degradation reactions lead to the formation of low molecular compounds which contribute to the sensory profile. Hydro-peroxides and secondary oxidation products can react with protein and amino acids during processing, heat treatment and storage period affecting the flavor, odor and texture of meat products (Frankel, 1998). The ripening process

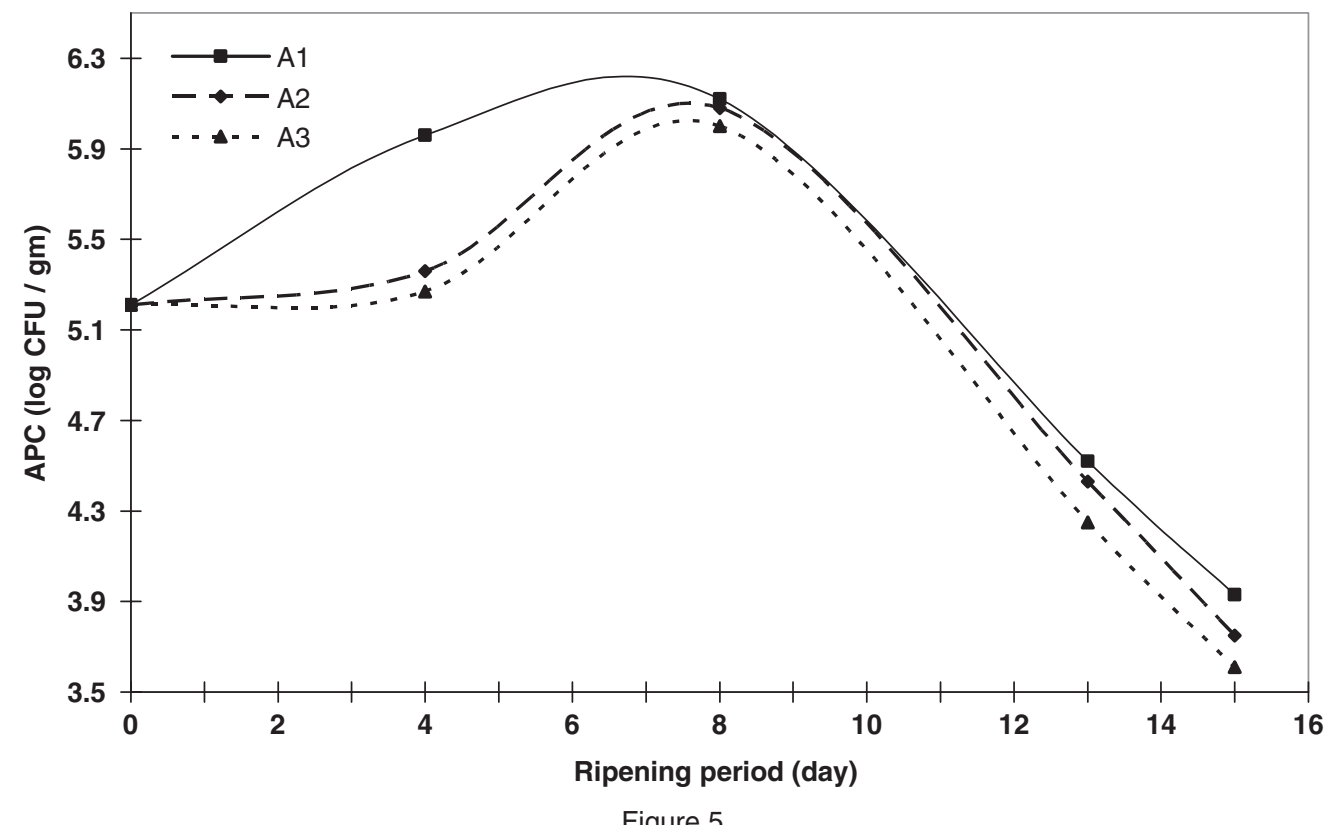

Figure 5

Aerobic plate count (APC) for dry fermented sausage during ripening period. $\mathrm{A} 1=$ Control sample; A2 $=$ Sample mixed with $0.025 \%$ sage oil extract; A3 = Sample mixed with $0.05 \%$ sage oil extract. 


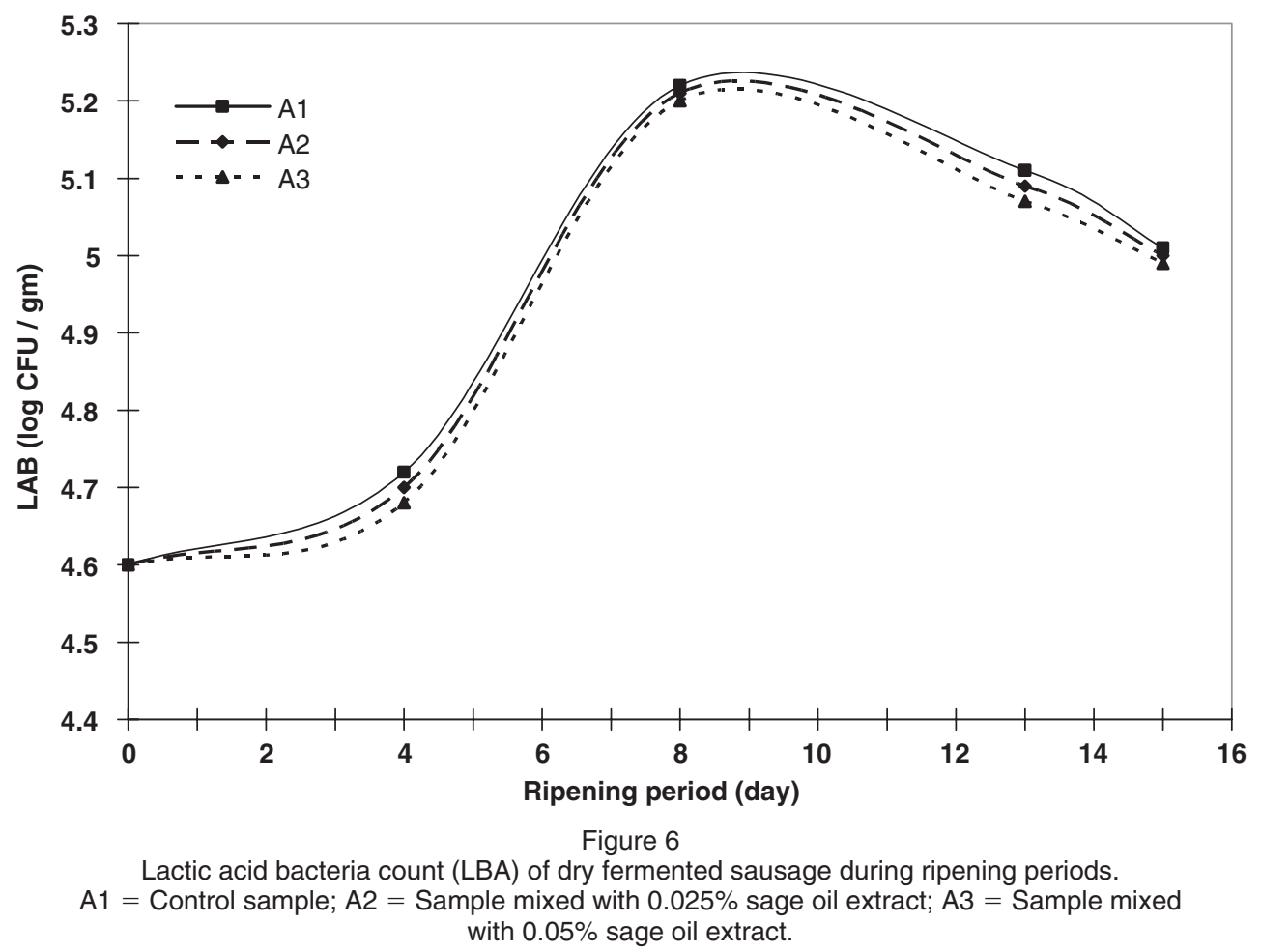

of fermented sausage gives the product its particular slicing ability, firmness, color and flavor (Ordonez et al., 1999).

The effect of ripening time and the addition of sage oil extract to the investigated dry fermented sausage on the overall sensory quality scores was determined (Table 2). The overall sensory quality of the sausage samples was noticed to be affected significantly $(p<0.05)$ by ripening time and addition of the used antioxidant extract. The overall sensory scores increased significantly during the first 8 days of the ripening period. The control sample (A1) was found to be of the lowest score compared to the other samples. The addition of sage oil extract with 0.025 and $0.05 \%$ to samples $\mathrm{A} 2$ and $\mathrm{A} 3$ respectively was found to improve their overall sensory scores.
At the $8^{\text {th }}$ day of ripening, the overall sensory quality of sausage samples (A2 and $A 3$ ) was higher than that of the control sample (A1). The order of acceptability was: $A 2$ nearly equal to $A 3$ and higher than the control sausage sample. At the end of the ripening time (15 days), sausage samples mixed with $0.05 \%$ sage oil extract (A3) gained the best overall sensory score.

\section{CONCLUSION}

Results of this study indicate that sage oil extract as a natural antioxidant could be utilized in dry fermented sausage, prepared from buffalo meat, in order to obtain a final product within acceptable biogenic amine levels, TBARS formation values and APC \& LAP counts as

Table 2

Overall sensory quality of the dry fermented sausage during the ripening period

\begin{tabular}{|c|c|c|c|c|c|c|c|c|}
\hline \multirow{3}{*}{$\begin{array}{c}\text { Ripening } \\
\text { period* }^{*} \\
\text { (day) }\end{array}$} & \multicolumn{6}{|c|}{ Sample } & \multirow{2}{*}{\multicolumn{2}{|c|}{$\begin{array}{c}\text { Main effect } \\
\text { of period }\end{array}$}} \\
\hline & \multicolumn{2}{|c|}{ A1 } & \multicolumn{2}{|c|}{ A2 } & \multicolumn{2}{|c|}{ A3 } & & \\
\hline & Mean & SD & Mean & SD & Mean & SD & Mean & SD \\
\hline 0 & \multicolumn{2}{|c|}{ NM } & \multicolumn{2}{|c|}{ NM } & \multicolumn{2}{|c|}{ NM } & & \\
\hline 4 & 4.250 & \pm 0.198 & 5.50 & \pm 0.269 & 5.50 & \pm 0.269 & $5.08 d$ & \pm 0.673 \\
\hline 8 & 6.20 & \pm 0.208 & 7.02 & \pm 0.355 & 7.22 & \pm 0.366 & $6.81 \mathrm{c}$ & \pm 0.552 \\
\hline 13 & 7.50 & \pm 0.382 & 7.95 & \pm 0.407 & 8.05 & \pm 0.413 & $7.83 b$ & \pm 0.406 \\
\hline \multirow{2}{*}{$\begin{array}{c}15 \\
\text { Main effect } \\
\text { of sample }\end{array}$} & 8.00 & \pm 0.410 & 8.75 & \pm 0.453 & 8.95 & \pm 0.464 & $8.57 a$ & \pm 0.564 \\
\hline & $6.49 \mathrm{~b}$ & \pm 1.570 & 7.31a & \pm 1.323 & $7.43 a$ & \pm 1.390 & & \\
\hline
\end{tabular}

Means with different letters within each column are significant at $\alpha 0.05$.

${ }^{*}$ Ripening at $(\mathrm{RH}) 90-60 \%$, at $25-18^{\circ} \mathrm{C}$. SD $=$ Standard Deviation. $\mathrm{NM}=$ not measured.

$A_{1}=$ control sample.

$A_{2}=$ sample mixed with $0.025 \%$ sage oil extract.

$A_{3}=$ sample mixed with $0.05 \%$ sage oil extract. 
well improved sensory quality. In view of human health, hygienic conditions should be applied and ripening periods should be strictly controlled to maintain quality and safety.

\section{REFERENCES}

Baydar H, Sagdic O, Gulcan O, karadogan T. 2004. Antibacterial activity and composition of essential oils from Origanum, Thymbra, an Satureja species with commercial importance in Turkey. Food Control 15,169-172.

Bover-Cid S, Hernandez-Jover T, Miguleles-Arrizado M.J., Vidal-Caron, M.C. 2003. Contribution of contaminant enterobacteria and lactic acid bacteria to biogenic amine accumulation in spontaneous fermentation of pork sausages. European Food Research and Technology 216, 477-482.

Bover-Cid S, Hugas N, Izquierdo-Pulido M, Vidal-Carson M C. 2001. Amino acid-decarboxylase activity of bacteria isolated from fermented pork sausages. International Journal of Food Microbiology 66,186-189.

Bozkurt H, Erkmen O. 2004. Effect of nitrate/nitrite on the quality sausage (sucuk) during ripening and storage. Journal of the Science of Food and Agriculture 84, 279-286.

Bozkurt H. 2006. Utilization of natural antioxidants: Green tea extract and Thymbra spicata oil in Turkish dry-fermented sausage. Meat Science 73, 442-450.

Bruna JM, Ordoñez JA, Fernandez M, Herranz B, De La Hoz L. 2001.Microbial and physico-chemical changes during the ripening of dry fermented sausages superficially inoculated with or having added an intracellular cell-free extract of Penicillium aurantiogriscum. Meat Science 59, 87-96.

Byun MW, Lee JW, Jo C, Yook HS. 2001. Quality properties of sausage made with gamma-irradiated natural pork and lamb casing. Meat Science 59, 223-228.

Cassel E, Vargas RMF, Martinez N, Lorenzo D, Dellacassa E. 2009.Steam distillation modeling for essential oil extraction process. Industrial crops and Products 29,172-176.

Chen X, Jo C, Lee JI, Ahn DU. 1999. Lipid oxidation, volatiles and color changes of irradiated pork patties as affected by antioxidants. Journal of Food Science 64, 16-19.

Coïsson JD, Ceruttti C, Travaglia F, Arlorio M. 2004. Production of biogenic amines in Salami italiani alla cacciatore PDO. Meat Science 67, 343-349.

De Las Rivas B, Ruiz-Capillas C, Carrascosa AV, Curiel JA., Jimenez-Colmenero F, Munoz R. 2008. Biogenic amine production by Gram- positive bacteria isolated from Spanish dry-cured "chorizo" sausage treated with high pressure and kept in chilled storage. Meat science $80,272-277$.

Deabes MMY. 2000. Studies on some biogenic amines in some meat and fish products with respect to other quality attributes. M.Sc. Theises, Food Science \& Technology Dept., Faculty of Agriculture, Al-Azhar Univr., Cairo, Egypt.

Dierick N, Vandekerckhove P, Demeyer D.1974. Changes in nonprotein nitrogen compounds during dry sausage ripening. Journal of Food Science 39,301-304.

Djenane D, Sánechez-Escalante A, Beltrán JA, Roncales P. 2003. Extention of the shelf life of beef stakes packaged in a modified atmosphere by treatment with rosemary and displayed under UV-free lighting. Meat Science 64, 417-426.
Dorman HjD, Peltoketo A, Hiltunen R, Tikkanen MJ. 2003. Characterization of the antioxidant properties of de-odorized aqueous extracts from selected Lamiacea Lamiaceae herbs. Food Chemistry 83, 255-262

Eerola S, Sagues AXR, Lilleberg L, Aalto H 1997. Biogenic amines in dry sausage during shelf-life storage. Zeitunig Lebensmittel Fur Unters Forsch. A, 205, 351-355.

Eitenmiller RR, Koehler PE, Regan PE. 1978. Tyramine in fermented sausage: factors affecting formation of tyrosine and tyrosine decarboxylase. Journal of Food Science 43, 689-693.

Erkmen O. 2000. Basic methods for the microbiological analysis of foods. Gaziantep Turkey; University of Gaziantep press.

Estevez M, Cava R. 2006. Effectiveness of rosemary essential oil as an inhibitor of lipid and protein oxidation: Contradictory effects in different types of frankfurters. Meat Science 72, 348-355.

Estevez M, Morcuende D, Ventanas J, Cava R. 2004. Effect of the addition of sage and Rosmary extracts on the oxidative stability of different types of liver pates. In proccedings of 50th ICOMST pp.194-195. Helsinki, Finland.

Ferreira V, Barbosa J, Vendeiro S, Mota A, Silva F, Monteiro MJ, Hogg T, Gibbs P, Teixeira P. 2006. Chemical and microbiological characterization of alheira: A typical Portuguese fermented sausage with particular reference to factors relating to food safety. Meat Science 73, 570575.

Formanek Z, Kerry JP, Higgins FM, Buckley DJ, Morrissey PA, Farkas J. 2001. Addition of synthetic and natural antioxidants to $\alpha$-tocopheryl acetate supplemented beef patties: Effects of antioxidants and packaging on lipid oxidation. Meat Science 58, 337-341.

Frankel EN. 1998. Foods. In Lipid oxidation-Volume 10 in the Oily Press lipid Library pp.187-226. Glasgow, Skotland: Bell, Bain Ltd.

Gonzales B, Diez V. 2002. The effect of nitrite and starter culture on microbiological quality of "chorizo"- a Spanish dry cured sausage. Meat Science 60, 295298.

Halasz A, Barath A, Simon-Sarkadi L, Holzapfel W. 1994. Biogenic amines and their production by microorganism in food. Trends in Food Science and Technology 5, 4249.

Hernandez-Jover TH, Pulido MI, Nogues MTV, Font AM, Carou MCV. 1997a. Effect of starter cultures on biogenic amine formation during fermented sausage production. Journal of Food Protection 60, 825-830.

Hernandez-Jover T, Izquierdo-Pulido M, Veciana-Nogués MT, Marine-font A, Vidal-Carou MC. 1997b. Biogenic amine and polyamine content in meat and meat products. Journal of Agricultural and Food Chemistry 45, 2098-2102.

Higdon JV, Frei B. 2003. Tea catechine and polyphenols: health effects, metabolism, and antioxidant functions. Critical Reviews in Food science and Nutrition, 43, 89-143.

Ibanez E, Kubatova A, Senorans FJ, Cavero S, Reglero G, Hawthorne SB. 2003. Subcritical water extraction of antioxidant compounds from rosemary plants. Journal of Agricultural and Food Chemistry 51, 375-382

Kayaardi S, Gok V. 2003. Effect of replacing beef fat with olive oil on quality characteristics of Turkish soudjouk (sucuk). Meat Science 66, 249-257.

Komprda T, Smèlā D, Pechovā P, Kalhotka J, ŝtenel J, Klejdus B. 2004. Effect of starter culture, spice mix 
and storage time and temperature on biogenic amine content of dry fermented sausages. Meat Science 67 607-616.

Latorre-Moratalla ML, Veciana-Nogués T, Bover-Cid S, Garriga M, Aymerich T, Zanardi E, Ianieri A, Fraqueza MJ, Patarata L, Drosinos EH, Laukova A, Talon R, Vidal-Carou MC.2008. Biogenic amine in traditional fermented sausage produced in selected European countries. Food Chemistry 107, 912-921.

Leroy F, Verluyent J, De Vuyst L. 2006. Functional meat starter cultures for improved sausage fermentation International Journal of Food Microbiology 106, 270285.

Lüke FK. 1994. Fermented meat products. Food Research International 27, 299-307.

Maijala RL and Eerola SH.1993a. Contaminant Lactic acid bacteria of dry sausage produced histamine and tyramine. Meat Science 35, 387-395.

Maijala R, Eerola S, Aho M, Hirn J. 1993b. The Effect of GDL-induced $\mathrm{pH}$ decrease on the formation of biogenic amines in meat. Journal of food protection 56, 125-129.

Manzocco L, Anese M, Nicoli M C.1998. Antioxidants properties of green tea extracts as affected by processing. Lebensmittel-Wissenschaft und Technologie 31, 694698.

McCarthy TL, Kerry JP, Kerry JF, Lynch PB, Buckley DJ. 2001. Evaluation of the antioxidant potential of natural food/plant extracts as compared with synthetic antioxidants and vitamin $E$ in raw and cooked pork patties. Meat Science 57, 45-52.

Mielnik MB, Signe S, Bjorg E, Grete S. 2008. By-products from herbs essential oil production as ingredient in marinade for turkey thighs. Food Science and Technology 41, 93-100.

Önal A. 2007. A review: Current analytical methods for the determination of biogenic amines in foods. Food Chemistry 103, 1475-1486.

Ordonez JA, Hierro EM, Bruna JM, de la Hoz L. 1999. Changes in the components of dry-fermented sausages during ripening. Critical Reviews in Food Science and Nutrition 39, 329-367.

Roig-Sagués AX, Hernández-Herrero M, López-Sabater El, Rodriguez-Jerez JJ, Mora-Ventura MT. 1999. Microbiological events during the elaboration of "fuet", a Spanish ripened sausages. Relationships between the development of histidine and tyrosine-decarboxylasecontaining bacteria and $\mathrm{pH}$ and water activity. European Food Research and Technology 209, 108-112
Ruiz-Capillas C, Jimenez-Colmenero F. 2004. Biogenic amines in meat and meat products. Critical Reviews in Food Science and Nutrition 44, 89-499.

Sağdiç O, Özcan M. 2002. Antibacterial activity of Turkish spice hydrolysis. Food Control 14, 141-143.

Samelis J, Metaxopoulos J, Vlassi M, Pappa A. 1998. Stability and safety of traditional Greek salami- a microbiological ecology study. International Journal of Food Microbiology 44, 69-82.

Santos-Buelga C, Peña-Egido MJ, Rivas-Gonzalo JC. 1986. Changes in tryamine during Chorizo-Sausages ripening. Journal of Food Science 51, 518-527.

Senoz B, Isikli N, Coksoyler N. 2000. Biogenic amines in Turkish sausage (sucuk). Journal of Food Science 65, 764-767.

Shalaby AR. 1996. Significance of biogenic amines to food safety and human health. Food Research International 29, 675-690.

Snedecor GW, Cochran G. 1990. Statistical Methods, $9^{\text {th }}$ Ed. lowa State Univer. Press, lowa, USA.

Suzzi G, Gardini F. 2003. Biogenic amines in dry fermented sausages: a review. International Journal of Food Microbiology 88, 41-54.

Tang S, Kerry JP, Sheehan D, Buckley DJ \& Morrissey PA.2001. Antioxidative effect of added tea catechins on susceptibility of cooked red meat, poultry and fish patties to lipid oxidation. Food Research International 34, 651-657.

Vinci G, Antonelli, ML 2002.Biogenic amines: quality index of freshness in red and white meat. Food control 13, 519-524.

Vural H. 1998. The use of commercial starter cultures in the production of Turkish semi-dry fermented sausages. Zeitschrift fur Lebensmittel-Untersuching und Forschung A 207, 410-412.

Waller A, Duncan DB. 1969. Multiple range and multiple test. Biometries, 11:1-24.

Wanasundara, U N, SHAHIDI, F. 1998. Antioxidant and pro-oxidant activity of green tea extracts in marine oils. Food Chemistry 63, 335- 342.

Yanishlieva NV, Marinova EM. 2001. Stabilization of edible oils with natural antioxidant. European Journal of Lipid Science and Technology 103, 752-767.

Zandi P, Gondon MH.1999. Antioxidant activity of extracts from old tea leaves. Food Chemistry 64, 285-288. 